\title{
EVALUASI INTERAKSI SOSIAL DAN AKSESIBILITAS PENYANDANG DISABILITAS PADA PELAYANAN AKADEMIK DI INSITUT AGAMA ISLAM NEGERI METRO
}

\author{
Aisyah Sunarwan \\ Institut Agama Islam Negeri (IAIN) Metro \\ Email: aisyahsunarwan@gmail.com

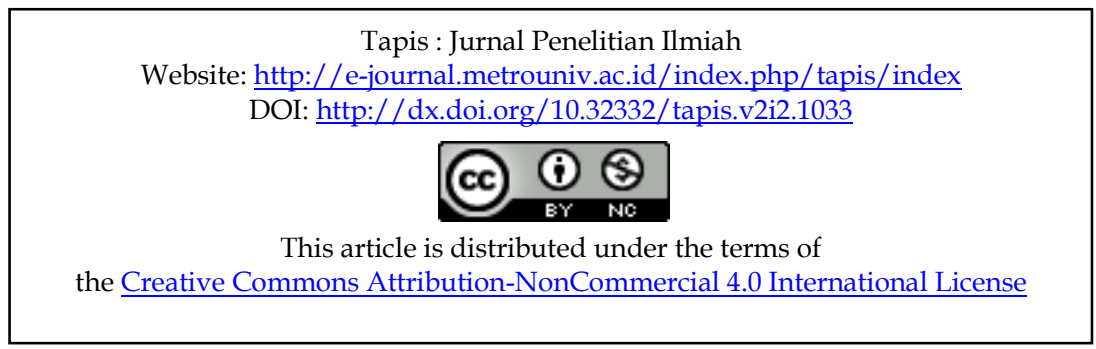

\begin{abstract}
The study about empowerment of people with disability is often done by government and social organizations. This can be seen from the publication of the regulation on the fulfillment of the rights of Personal with Disability (PwDs) summarized in Law number 8 of 2016. Previously, children with special needs (disable) get their right of education only in special schools, thus it impacts to social interaction with children who have no obstacles.
\end{abstract}

Inclusive education offers an integrated education model. Inclusive education is conducted to train the interaction of all people from various circles in order to build friendship and association naturally. It also to motivate children who have special needs to be more confident.

Through this background the writer conducted research on the interaction process of people with disability and accessibility and academic services at State Institution for Islamic Studies (IAIN) of Metro by using qualitative descriptive method. It is explorative or developmental in interpreting and drawing conclusions. The result of this research is the process of social interaction between PwDs and the academic community runs fairly. The academic service and the fulfillment of the right to education at IAIN Metro are excellent. However, architectural accessibility on the campus of IAIN Metro needs the significant shortcomings that require continuous improvement. So that the IAIN Metro environment can become an educational institution that is friendly to the environment and can realize inclusive education.

Keyword: Social Interaction, Accessibility, and Personal with Disabdility
Abstrak
Diskursus pemberdayaan penyandang disabilitas kerap dilakukan oleh pemerintah serta lembaga-lembaga swadaya masyarakat. Hal ini terlihat dari terbitnya regulasi tentang pemenuhan hak-hak penyandang disabilitas yang terangkum dalam Undang -Undang nomor 8 tahun 2016. Sebelumnya, 
anak-anak yang memiliki kebutuhan khusus (difabel) mendapatkan hak pendidikan hanya di sekolah khusus, sehingga berdampak pada interaksi sosial terhadap anak-anak yang tidak memiliki hambatan.

Pendidikan inklusif menawarkan model pendidikan terpadu dan terintegrasi. pendidikan Inklusif dilaksanakan untuk melatih interaksi semua orang dari berbagai kalangan agar terjalin pertemanan dan pergaulan secara wajar. Serta untuk memotivasi anak-anak yang memiliki kebutuhan khusus atau anak-anak yang kurang memiliki ekonomi baik supaya lebih percaya diri.

Melalui latarbelakang tersebut penulis melakukan penelitian tentang proses interaksi penyandang disabilitas serta aksesibilitas dan pelayanan akademik pada IAIN Metro dengan menggunakan metode deskriftif kualitatif yang bersifat eksploratif atau developmental dalam menginterpretasi dan mengambil kesimpulan. Hasil dari penelitian ini yaitu proses interaksi sosial antara penyandang disabilitas dan civitas akademika berjalan secara wajar. Pelayanan akademik serta pemenuhan hak pendidikan di IAIN Metro sangat baik. Namun demikan, aksesibilitas arsitektural di kampus IAIN Metro masih terdapat kekurangan yang cukup signifikan sehingga memerlukan perbaikan-perbaikan yang terus - menerus. Sehingga lingkungan kampus IAIN Metro menjadi lembaga pendidikanyang ramah terhadap lingkungan dan dapat mewujudkan pendidikan inklusif.

Kata Kunci: Interaksi Sosial, Aksesibilitas, Penyandang Disabilitas

\section{A. PENDAHULUAN}

Pendidikan merupakan kebutuhan mendasar bagi setiap warga negara Indonesia dan sangat bermanfaat bagi perkembangan sikap maupun psikologis peserta didik dan meningkatkan potensi akademik. Seperti dijelaskan dalam Undang Undang SISDIKNAS nomor 20 tahun 2003 bahwa pendidikan untuk mengembangkan potensi diri secara aktif supaya memiliki pengendalian diri, kecerdasan, keterampilan¹. Setiap warga negara berhak menentukan jenis pendidikan yang akan mereka tempuh, baik formal maupun non-formal demi memaksimalkan potensi, kecerdasan, sehingga dapat tercipta generasi yang mandiri mampu berkarya. Berangkat dari pemikiran diatas, Institut Agama Islam Negeri (IAIN) Metro hadir guna memenuhi kebutuhan masyarakat akan Pendidikan.

\section{8}

1 “Undang-Undang Republik Indonesia Nomor 20 Tahun 2003," accessed December 20, content/uploads/2016/08/UU_no_20_th_2003.pdf. 
Institut Agama Islam Negeri (IAIN) Metro adalah salah satu perguruan tinggi di Metro yang memiliki mahasiswa aktif sebanyak 6853 mahasiswa yang terdiri dari Fakultas Tarbiyah, Fakultas Syari'ah, Fakultas Ekonomi Bisnis Islam, dan Fakultas Dakwah². Dari sekian banyak mahasiswa tidak semuanya dalam kondisi normal atau tanpa kelainan. Berdasarkan survey yang dilakukan oleh peneliti pada tanggal 29 s.d 31 Maret 2017 terdapat lebih dari 10 mahasiswa dengan disabilitas yang bervariasi. Sebanyak 6 mahasiswa yang berasal dari Jurusan berbeda mengalami buta sebelah atau salah satu dari kedua matanya tidak berfungsi dengan baik, satu mahasiswa dari prodi S1-PBS mengalami pendengaran dan penglihatan yang kurang normal, seorang mahasiswa dari D3-PBS mengalami pembengkakan dibagian pipi, seorang mahasiswa Tunanetra dari Jurusan PAI, seorang mahasiswa D3-PBS mengalami kerdil atau dalam bahasa latin disebut sebagai Cretinisme.

Terdapat peningkatan jumlah mahasiswa disabilitas di IAIN Metro, meskipun belum dikatakan signifikan. Namun dalam menyikapi kondisi ini, belum ada program pendidikan Inklusi bagi para mahasiswa penyandang disabilitas ini yang merujuk pada Convention on the Rights of Persons with Disabilities (CRPD) berupa lampiran UU RI nomor 19/2011 tentang Ratifikasi CRPD yang menyatakan bahwa penyandang disabilitas juga berhak untuk mendapatkan pendidikan tinggi. Pada pasal 24 ayat 5 disebutkan bahwa Negara harus menjamin penyandang disabilitas supaya dapat mengakses pendidikan umum menengah, pelatihan kejuruan, pendidikan dewasa, dan pembelajaran seumur hidup tanpa diskriminasi dan atas dasar kesetaraan dengan yang lainnya. ${ }^{3}$

Untuk mencapai tujuan ini, Negara harus menyediakan lingkungan belajar yang memadai bagi penyandang disabilitas. Hal ini menunjukkan bahwa penyandang disabilitas memiliki hak yang sama dalam mengakses pendidikan di perguruan tinggi. Namun yang terjadi saat ini belum banyak perguruan tinggi yang secara khusus memberikan keluasan akses bagi penyandang disabilitas atau menyediakan lingkungan yang sesuai dengan kondisi penyandang disabilitas. Misal di IAIN Metro khususnya di Fakultas Tarbiyah dan Ilmu Keguruan, meskipun ada mahasiswa disabilitas netra,

3 “Undang-Undang Republik Indonesia Nomor 19 Tahun 2011," accessed December 10, 2018, https://www.bphn.go.id/data/documents/11uu019.pdf. 
namun tidak terdapat alat bantu khusus bagi tunanetra atau desain lingkungan yang sifatnya universal, atau lingkungan yang ramah bagi para penyandang disabilitas.

Keberadaan mahasiswa yang memiliki hambatan atau perbedaan kemampuan yang lebih dikenal dengan "disabilitas" menjadi bagian dari IAIN Metro perlu mendapatkan perhatian lebih baik dari pemerintah maupun masyarakat sekitar. Seperti yang dijelaskan dalam Undang-undang Dasar 1945 pasal 31 ayat 1 dan Undang-Undang Nomor 2 tahun 1989 tentang Sistem Pendidikan Nasional bab III ayat 5 dinyatakan bahwa setiap warga negara mempunyai kesempatan yang sama memperoleh Pendidikan ${ }^{4}$.

IAIN Metro memiliki potensi yang cukup besar untuk dapat menerapkan pendidikan inklusif karena sudah didukung dengan SDM yang berkualitas, sumber dana yang memadai, dan dukungan manajemen pendidikan tinggi yang handal, disamping itu animo masyarakat untuk masuk ke perguruan tinggi tersebut sangat tinggi. Hal ini terbukti dengan beberapa mahasiswa disabilitas seperti tunanetra dan tunadaksa yang telah menjadi mahasiswa di IAIN Metro. Oleh karena itu, perguruan tinggi tersebut perlu memberikan akses bagi mereka dengan menerapkan pendidikan inklusif serta mempersiapkan sarana pendukung pembelajaran dan desain kurikulum yang sesuai dengan karakteristik penyandang disabilitas.

Melihat kompleksnya permasalahan dalam pemenuhan hak-hak bagi penyandang disabilitas untuk memperoleh kesamaan pendidikan diatas, maka penulis melakukan penelitian tentang evaluasi interaksi penyandang disabilitas serta aksesibilitas dan pelayanan di IAIN Metro. Urgensi pelaksanaan penelitian ini yaitu untuk merealisasikan undang undang nomor 8 tahun 2016 tentang Penyandang Disabilitas, terutama kesamaan hak mendapat pendidikan. Kemudian untuk mengukur sejauh mana perkembangan pendidikan Inklusif yang telah marak di Indonesia terutama pada tingkat pendidikan dasar dan menengah.

\section{B. KAJIAN TEORI}

\section{Evaluas}

4 “Undang-Undang Republik Indonesia Nomor 2 Tahun 1989," accessed December 10, 2018, https:/ /jdih.kemenkeu.go.id/fulltext/1989/2TAHUN 1989UU.HTM. 
Secara harfiah kata evaluasi berasal dari bahasa Inggris evaluation; dalam bahasa Arab: al-Taqdir, dalam bahasa Indonesia berarti: penilaian. Akar katanya adalah value; dalam bahasa Arab al-Qimah, dalam bahasa Indonesia berarti: nilai. ${ }^{5}$ Menurut definisi ini, maka istilah evaluasi itu menunjukan kepada atau mengandung pengertian: suatu tindakan atau suatu proses untuk menentukan nilai dari sesuatu. 6,7

Dalam arti luas, evaluasi adalah suatu proses merencanakan, memperoleh, dan menyediakan informasi atau data yang sesuai dan diperlukan untuk membuat alternatif-alternatif keputusan8,9. Lebih lanjut, evaluasi merupakan proses yang sistematis dan berkelanjutan untuk mengumpulkan, mendiskripsikan, menginterpretasikan dan menyajikan informasi tentang suatu program untuk dapat dipergunakan sebagai dasar membuat keputusan, menyusun kebijakan maupun menyusun program selanjutnya. ${ }^{10}$

Dari penjelasan diatas dapat ditarik kesimpulan bahwa evaluasi adalah kegiatan untuk menentukan manfaat, baik dan buruknya sesuatu, dan juga dapat mengetahui berjalannya sebuah program. Proses dalam evaluasi ini melalui beberapa proses yaitu mengidentifikasi, mengklarifikasi dan mengaplikasikan kriteria untuk dapat menentukan kelebihan dan kekurangan. Apabila sudah ditentukan kelebihan dan kekurangannya evaluasi dapat menjadi dasar keputusan apakah program harus dilanjutkan, diganti atau dihentikan.

\section{Interaksi Sosial}

Setiap individu dalam menjalankan kehidupan tidak lepas dari kepentingan dan hubungan sosial dengan orang lain. Sebab interaksi sosial tersebut adalah bagian dari kebutuhan setiap orang. Interaksi sosial adalah hubungan antar individual, antar kelompok, atau individu dengan kelompok. ${ }^{11}$ Interaksi sosial adalah sesuatu

${ }^{5}$ Anas Sudijono, Pengantar Evaluasi Pendidikan (Jakarta: Raja Grafindo Persada, 2011), 1.

${ }^{6}$ Anas Sudijono, Pengantar Evaluasi Pendidikan.

7 Wina Sanjaya, Kurikulum Dan Pembelajaran:Teori Dan Praktik PengembanganKurikulum Tingkat Satuan Pendidikan (KTSP) (Jakarta: Kencana, 2008), 333.

${ }^{8}$ Ngalim Purwanto, Prinsip-Prinsip Dan Teknik Evaluasi Pengajaran (Bandung: Remaja Rosdakarya, 2009), 3.

9 Ramayulis, Ilmu Pendidikan Islam (Jakarta: Kalam Mulia, 2011), 221.

10 Eko Putro Widoyoko, Evaluasi Program Pembelajaran Panduan Praktis Bagi Pendidik Dan Calon Pendidik (Yogyakarta: Pustaka Pelajar, 2016), 5.

${ }^{11}$ Elly M. Setiadi, Ilmu Sosial Dan Budaya Dasar (Jakarta: Kencana Prenada Media Group, 2007), 9 . 
hubungan antara dua individu atau lebih. Sehingga dalam proses tersebut dapat mengubah atau memengaruhi kedua pihak.

\section{Aksesibilitas}

Aksesibilitas adalah jarak yang mampu dicapai dengan maksimum dari satu tempat ke tempat lain. Selain itu aksesibilitas juga dapat diartikan sebagai konsep geografi yang berkaitan dengan kemudahan sarana dan prasarana untuk mencapai suatu tempat. Jadi, aksesibilitas tidak hanya tergantung pada jarak tetapi juga tergantung pada sarana dan prasarana penunjang.

Aksesibilitas adalah suatu ukuran kenyamanan atau kemudahan lokasi tata guna lahan berinteraksi satu sama lain, dan mudah atau sulitnya lokasi tersebut dicapai melalui transportasi. ${ }^{12}$ Aksesibilitas adalah ukuran kemudahan yang meliputi waktu, biaya, dan usaha dalam melakukan perpindahan antara tempat-tempat atau kawasan dari sebuah system.

\section{Penyandang Disabilitas}

Penyandang diartikan dengan orang yang mengalami atau menderita sesuatu. Sedangkan disabilitas berasal dari kata serapan bahasa Inggris disability (jamak: disabilities) yang berarti cacat atau ketidakmampuan ${ }^{13}$. Jadi penyandang disabilitas adalah seseorang yang mengalami ketidakmampuan dalam beberapa hal.

Penyandang disabilitas adalah individu dengan hambatan fisik dan/atau mental yang terdiri dari penyandang disabilitas fisik mental dan ganda. ${ }^{14}$ Dari dua definisi tersebut dapat dikerucutkan bahwa penyandang disabilitas adalah seseorang yang mengalami hambatan fisik, mental dan intelektual. Disabilitas mental yang memiliki kecerdasan tinggi, sering dikenal dengan orang cerdas istimewa, dan berbakat istimewal. Disabilitas mental rendah yang memiliki kecerdasan intelektual di bawah 100 dikenal dikenal juga berkesulitan belajar dan tuna grahita (Down Syindrome).

12 Tjiptono Fandy, Prinsip-Prinsip Total Quality Service,Andi Offset (Yogyakarta: Andi Offset, 2005), 17.

${ }^{13}$ KamusBesarBahasaIndonesiaPusatBahasa,EdisiKeempat,(DepartemenPendidikanNasi onal: Gramedia,Jakarta,2008).

14 Pemerintah Daerah Provinsi Lampung, "Pelayanandan Pemenuhan Hak-Hak Penyandang Disabilitas," Pub. L. No. 10 (2013). 
Disabilitas Fisik adalah segala hambatan yang disebabkan oleh fisik/jasad. Disabilitas ini meliputi beberapa macam, yaitu: Pertama, Kelainan Tubuh (Tuna Daksa). Individu yang memiliki hambatan fisik dan gerak mototrik. Kedua, Kelainan Indera Penglihatan (Tuna Netra). Tunanetra adalah individu yang memiliki hambatan dalam penglihatan. Ketiga, Kelainan Pendengaran (Tuna rungu). Tuna rungu adalah individu yang memiliki hambatan dalam pendengaran baik permanen maupun tidak permanen. ${ }^{15}$ Sementara penyandang disabilitas yang teridentifikasi memiliki kedua hambatan itu disebut Tuna Ganda.

\section{Pelayanan Publik}

Dalam suatu lembaga pemerintahan yang berorientasi pada kesejahteraan rakyat, pelayanan publik merupakan salah satu unsur penting untuk dihadirkan. Pelayanan dapat diartikan sebagai pemberian keperluan perorangan atau masyarakat yang mempunyai kepentingan pada organisasi itu sesuai dengan aturan pokok dan tata cara yang ditentukan. Pelayanan Publik menjadi sorotan utama dalam penyelenggaraan pemerintahan. Menurut Kamus Besar Bahasa Indonesia, pelayanan memiliki tiga makna, (1) perihal atau cara melayani; (2) usaha melayani kebutuhan orang lain dengan memperoleh imbalan atau uang; (3) kemudahan yang diberikan sehubungan dengan jual beli barang atau jasa. Pelayanan Publik atau pelayanan umum dapat didefinisikan sebagai segala bentuk jasa pelayanan, baik dalam bentuk barang publik maupun jasa publik yang pada prinsipnya menjadi tanggung jawab dan dilaksanakan oleh instansi pemerintah di pusat, di daerah, dan di lingkungan Badan Usaha Milik Negara atau Badan Usaha Milik Daerah, dalam upaya pemenuhan kebutuhan masyarakat maupun dalam rangka pelaksanaan ketentuan peraturan perundang-undangan. ${ }^{16}$

\section{Pendidikan Inklusif}

Sampai saat ini masih banyak anggota masyarakat yang belum mengetahui dan menyadari adanya pendidikan Inklusif - sebuah pendidikan integrasi yang memberikan kesempatan pada penyandang disabilitasuntuk belajar bersama anak-

\footnotetext{
${ }^{15}$ Pemerintah Daerah Provinsi Lampung.

${ }^{16}$ Ratminto and Atik Septi Winarsih, Manajemen Pelayanan (Yogyakarta: Pustaka Pelajar, 2007), 4-5.
} 
anak non- kebutuhan khusus di sekolah reguler. Pendidikan model ini merupakan sebuah solusi untuk memberikan akses seluas-luasnya bagi anak yang berkebutuhan khusus, sekurang-kurangnya mereka bisa dengan mudah bergaul secara normal. Kehadiran pendidikan Inklusif merupakan upaya untuk menghapus batas yang selama ini muncul ditengah masyarakat, dengan istilah anak yang normal dan anak penyandang cacat. Model pendidikan Inklusif adalah sekolah yang ramah terhadap lingkungan, saling menghargai keterbatasan dan menghormati sesama.

Penyelenggaraan pendidikan untuk semua dalam seting Inklusif merupakan amanah undang undang yang harus dilaksanakan meski dengan berbagai persoalanpersoalan pendidikan yang terus menderu sistem pendidikan kita. Oleh karena itu pelaksana program Inklusif harus secara serius memperjuangkan hak-hak penyandang disabilitas untuk mendapatkan pendidikan yang layak.

Permendiknas mengamanatkan bahwa setiap sekolah memberikan hak yang sama bagi seluruh peserta didik, demi terciptanya pendidikan untuk semua. Karna indikasi pendidikan yang baik tentunya tidak hanya mengedepankan segudang prestasi dari berbagai kompetisi yang diperuntukkan bagi anak-anak non- kebutuhan khusus. Tapi juga turut memberikan kesempatan yang seluas-luasnya bagi anakanak yang memiliki keberbutuhan khusus untuk dapat mengenyam pendidikan yang sama serta turut berprestasi di berbagai bidang.

Selama ini anak-anak yang memiliki kebutuhan khusus (difabel) ditempatkan di tempat yang khusus dan disediakan fasilitas sesuai dengan derajat dan jenis ketunaanya yang disebut dengan Sekolah Luar Biasa (SLB). Itu pun dalam jenjang pendidikan yang terbatas yaitu mulai sekolah dasar hingga menengah. Sementara pendidikan tinggi masih belum ada. Hal inilah kemudian yang mendorong pemerintah untuk menerapkan pendidikan inklusif di perguruan tinggi.

Pada prinsipnya pendidikan Inklusif dilaksanakan untuk melatih interaksi semua anak dari berbagai kalangan agar terjalin pertemanan secara wajar. Dan untuk memotivasi anak-anak yang memiliki keberbutuhan khusus serta anak-anak yang kurang memiliki ekonomi baik supaya lebih percaya diri terhadap lingkungan di sekitarnya. Meskipun model Sekolah Luar Biasa telah memberikan berbagai fasilitas pembelajaran yang relatif komplit, namun sejauh ini efek sekolah segregasi telah 
melahirkan komunitas eksklusif anak-anak penyandang disabilitas, dan ini terjadi secara merata di tiap-tiap lulusan. Dampaknya anak yang telah lulus, kesulitan bersosialisasi dengan masyarakat serta susah mendapatkan pekerjaan yang layak. Persoalan ini tidak boleh dibiarkan berlarut-larut, pemerintah harus sigap dan tanggap menanganinya. Tentunya dengan menyediakan pendidikan yang setara serta sebuah lapangan kerja yang sama dengan anak-anak yang normal untuk keberlanjutan masa depan mereka.

Berdasarkan pada persamaan hak bahwa setiap warga negara mendapat pendidikan yang sama, maka pendidikan Inklusif perlu digalakkan di setiap lembaga pendidikan tinggi. Sejauh ini pendidikkan Inklusif memang tengah bergerak progresif, meskipun hanya terjadi pada jenjang pendidikan dasar dan pendidikan menengah. Dengan adanya program pendidikan Inklusif yang bersifat terbuka bagi masyarakat, maka upaya menciptakan pendidikan yang ramah terhadap semua perbedaan dan menghormati sebuah keterbatasan sungguh sebuah cita-cita yang luhur yang sudah seharusnya diwujudkan pada pendidikan tinggi.

\section{METODE PENELITIAN}

Penelitian ini termasuk jenis penelitian deskriptif kualitatif. Penelitian deskriptif bermaksud mendeskripsikan atau menggambarkan detail dari masalah-masalah penelitian, sehingga dapat diketahui akar pokok permasalahan yang dikaji, sekaligus dapat menyajikan solusi sesuai dengan sifat masalah yang dihadapi. ${ }^{17}$

Lokasi penelitian ini dilaksanakan di perguruan Tinggi Negeri di Metro yaitu Institut Agama Islam Negeri (IAIN) Metro pada Fakultas Tarbiyah, Syariah, Ekonomi dan Bisnis Islam dengan teknik pengumpulan data melalui wawancara mendalam (Indepth Interview), observasi dan dokumentasi. ${ }^{18}$.

\section{HASIL PENELITIAN DAN PEMBAHASAN}

\section{Deskripsi Hasil Penelitian}

${ }^{17}$ Suharsimi Arikunto, Prosedur Penelitian Suatu Pendekatan Praktik (Yogyakarta: Rineka Cipta, 2006).

${ }^{18}$ Deddy Mulyana, Metodologi Penelitian Kualitatif, Paradigma Ilmu Komunikasi Dan Ilmu Sosial Lainnya (Jakarta: PT Remaja Rosda Karya, 2001), 181. 
Pada tahun 2017 terdapat 13 mahasiswa penyandang diabilitas di Institut Agama Islam Negeri (IAIN) Metro, diantaranya Tuna Netra low vision, cretinisme, Tuna Daksa, dan lain sebagainya.

Hasil wawancara mengenai interaksi sosial, aksesibilitas dan format Pendidikan inklusif di Institut Agama Islam Negeri (IAIN) Metro, dapat dilihat pada tabel berikut:

Tabel 1. Hasil Wawancara

\begin{tabular}{|c|c|c|}
\hline \multicolumn{2}{|c|}{ INDIKATOR } & HASIL EVALUASI \\
\hline \multirow{6}{*}{$\begin{array}{l}\text { Interaksi } \\
\text { Sosial } \\
\text { Mahasiswa } \\
\text { Penyandang } \\
\text { Disabilitas }\end{array}$} & $\begin{array}{l}\text { Hubungan } \\
\text { individu atau } \\
\text { kelompok }\end{array}$ & $\begin{array}{l}80 \% \text { mahasiswa mengungkapkan bahwa merasa } \\
\text { minder ketika berinteraksi dengan teman sejawat. } \\
\text { Terutama pada awal perkuliahan. Sehingga membuat } \\
\text { mereka merasa enggan untuk meminta bantuan. }\end{array}$ \\
\hline & Komunikasi & $\begin{array}{l}\text { Pada prinsipnya terjadi hubungan yang baik antara } \\
\text { penyandang disabilitas dengan mahasiswa lainnya, } \\
\text { sehingga terjadi komunikasi yang lentur. Namun ada } \\
20 \% \text { mahasiswa yang merasa pernah dikucilkan ketika } \\
\text { meminta bantuan sesuatu. }\end{array}$ \\
\hline & Kerjasama & $\begin{array}{l}\text { Kerjasama yang dilakukan dalam mengerjakan tugas } \\
\text { perkuliahan berjalan secara lancar dan nyaman. Baik } \\
\text { ketika mengerjakan tugas kelompok maupun saat } \\
\text { presentasi. }\end{array}$ \\
\hline & Interaksi & $\begin{array}{l}\text { Interaksi yang dilakukan dengan teman secara umum } \\
\text { terjalin baik, namun } 20 \% \text { mahasiswa merasa kurang } \\
\text { diterima. }\end{array}$ \\
\hline & $\begin{array}{l}\text { Usaha } \\
\text { mencapai } \\
\text { keinginan }\end{array}$ & $\begin{array}{l}\text { Seluruh mahasiswa bersemangat untuk mencapai } \\
\text { keinginan dan cita-citanya terwujud dengan baik. Dan } \\
\text { orangtua sangat mendukung dan memotivasi hal } \\
\text { tersebut. }\end{array}$ \\
\hline & $\begin{array}{l}\text { Tindakan sadar } \\
\text { memberikan } \\
\text { respon }\end{array}$ & $\begin{array}{l}\text { Secara umum masing-masing mahasiswa memiliki } \\
\text { persamaan responsibilitas, yaitu sering menerima dan } \\
\text { memberi bantuan dalam banyak hal. }\end{array}$ \\
\hline
\end{tabular}




\begin{tabular}{|c|c|c|}
\hline & $\begin{array}{l}\text { Meniru suatu } \\
\text { perbuatan }\end{array}$ & $\begin{array}{l}100 \% \text { mahasiswa menyatakan bahwa orangtua adalah } \\
\text { role mode atau sosok paling dikagumi dan berperan } \\
\text { dalam memberikan semangat. }\end{array}$ \\
\hline & $\begin{array}{l}\text { Menarik } \\
\text { perhatian orang } \\
\text { lain }\end{array}$ & $\begin{array}{l}80 \% \text { mahasiswa penyandang disabilitas mencoba } \\
\text { untuk menarik perhatian teman-temannya dengan } \\
\text { terus meningkatkan kemapuan menulis, sedangkan } \\
20 \% \text { melakukannya dengan mengikuti kegiatan } \\
\text { organisasi. }\end{array}$ \\
\hline & $\begin{array}{l}\text { Bersaing secara } \\
\text { damai/sehat }\end{array}$ & $\begin{array}{l}\text { Seluruh mahasiswa bersaing secara wajar dalam setiap } \\
\text { mata kuliah yang diampu oleh dosen. }\end{array}$ \\
\hline & $\begin{array}{l}\text { Penyelesaian } \\
\text { konflik }\end{array}$ & $\begin{array}{l}\text { Seluruh mahasiswa berusaha menyelesaikan } \\
\text { masalah/konflik secara individual. Dan meminta } \\
\text { bantuan teman sejawat ketika persoalan tersebut betul- } \\
\text { betul membutuhkan bantuan. }\end{array}$ \\
\hline $\begin{array}{l}\text { pemenuhan } \\
\text { aksesibilitas } \\
\text { penyandang }\end{array}$ & $\begin{array}{l}\text { Kemudahan } \\
\text { memperoleh } \\
\text { layananan }\end{array}$ & $\begin{array}{l}\text { Pelayanan lembaga secara umum baik. Tidak ada } \\
\text { kendala yang menyulitkan secara signifikan. }\end{array}$ \\
\hline disabilitas & $\begin{array}{l}\text { Mudah } \\
\text { mengakses } \\
\text { transportasi }\end{array}$ & $\begin{array}{l}80 \% \text { mahasiswa merasa akses transportasi sudah cukup } \\
\text { baik, hanya } 20 \% \text { yang masih membutuhkan bantuan } \\
\text { teman dan orang tua untuk datang ke kampus. }\end{array}$ \\
\hline & $\begin{array}{l}\text { Mudah } \\
\text { mengakses } \\
\text { informasi }\end{array}$ & $\begin{array}{l}\text { Informasi yang berupa pengumuman dari lembaga } \\
\text { semuanya mudah diakses baik offline maupun online. }\end{array}$ \\
\hline & $\begin{array}{l}\text { Mudah } \\
\text { berkomunikasi }\end{array}$ & $\begin{array}{l}\text { Secara umum mahasiswa tidak memiliki kendala } \\
\text { dalam berkomunikasi. }\end{array}$ \\
\hline & Diskriminatif & $\begin{array}{l}\text { Perhatian teman dalam setiap pergaulan baik, tidak } \\
\text { ada perlakuan yang berbeda. Perlakuan dan sikap } \\
\text { dosen baik tanpa membeda-bedakan mahasiswa. }\end{array}$ \\
\hline & $\begin{array}{l}\text { Memperoleh } \\
\text { hak yang sama }\end{array}$ & $\begin{array}{l}\text { Semua mahasiswa mendapatkan hak yang sama dalam } \\
\text { pemenuhan fasilitas. }\end{array}$ \\
\hline $\begin{array}{l}\text { Format } \\
\text { pendidikan } \\
\text { Inklusif di }\end{array}$ & $\begin{array}{l}\text { Menyatukan } \\
\text { penyandang } \\
\text { disabilitas } \\
\text { dengan yang }\end{array}$ & $\begin{array}{l}\text { Proses pembelajaran berjalan secara inklusif dan ramah } \\
\text { terhadap penyandang disabilitas. }\end{array}$ \\
\hline
\end{tabular}




\begin{tabular}{|l|l|l|}
\hline $\begin{array}{l}\text { Perguruan } \\
\text { Tinggi }\end{array}$ & $\begin{array}{l}\text { normal dalam } \\
\text { satu kelas }\end{array}$ & \\
& $\begin{array}{l}\text { Pengembangan } \\
\text { potensi pribadi }\end{array}$ & $\begin{array}{l}40 \% \text { mahasiswa hobi menulis dan 20\% hobi mengikuti } \\
\text { kegiatan kemahasiswaan }\end{array}$ \\
\cline { 2 - 4 } & $\begin{array}{l}\text { Keaktifan } \\
\text { dalam belajar }\end{array}$ & $\begin{array}{l}\text { Secara umum mahasiswa melaksanakan pembelajaran } \\
\text { aktif. Mengerjakan tugas dari dosen dan berdiskusi } \\
\text { aktif dengan semua mahasiswa. }\end{array}$ \\
\cline { 2 - 4 } & $\begin{array}{l}\text { Memiliki } \\
\text { kekuatan } \\
\text { spiritual } \\
\text { keagamaan }\end{array}$ & $\begin{array}{l}\text { Seluruh mahasiswa melaksanakan kewajibannya } \\
\text { terhadap Tuhan. Meskipun ada beberapa yang tidak } \\
\text { tepat waktu. }\end{array}$ \\
\cline { 2 - 4 } & $\begin{array}{l}\text { Mampu } \\
\text { mengendalikan } \\
\text { diri }\end{array}$ & $\begin{array}{l}\text { Dengan kondisi yang memiliki hambatan saat ini } \\
\text { seluruh mahasiswa yang diwawancarai mampu } \\
\text { mengendalikan diri. }\end{array}$ \\
\cline { 2 - 4 } & Kepribadian & $\begin{array}{l}\text { Kepribadian para mahasiswa secara normatif memiliki } \\
\text { karakter baik. }\end{array}$ \\
\cline { 2 - 4 } & $\begin{array}{l}\text { Kecara umum kecerdasan mahasiswa berada pada } \\
\text { posisi standar. }\end{array}$ \\
\cline { 2 - 4 } & $\begin{array}{l}\text { Kesetaraan interaksi dalam setiap pembelajaran cukup } \\
\text { nyaman. }\end{array}$ \\
\hline
\end{tabular}

Dari table 2 diatas diketahui bahwa terdapat tiga bahasan yang sesuai dengan rumusan masalah yaitu tentang interaksi sosial, Pemenuhan Aksesibilitas, dan format Pendidikan inklusif di IAIN Metro. Interaksi sosial mahasiswa penyandang disabilitas yang terjadi di IAIN Metro bahwa sebagian besar dari mereka merasa minder dan kurang percaya diri dengan kondisi yang mereka alami terutama ketika diawal perkuliahan. Selain itu terdapat mahasiswa yang dikucilkan karena kondisi yang ada. Hubungan komunikasi yang awalnya kurang baik, pada akhirnya mengalami kemajuan dengan merasa lebih beryukur dan mereka mampu menjalin hubungan yang baik dengan teman-teman mereka.

Hubungan yang baik antara mahasiswa dengan teman memberikan dampak baik dalam meningkatkan kemampuan interaksi kerjasama dalam hal perkuliahan, 
seperti berperan aktif mengerjakan tugas kelompok ketika akan melakukan presentasi. Meskipun demikian 20\% mahaasiswa merasa bahwa keberadaannya kurang diterima. Pada dasarnya mahasiswa memiliki semangat yang tinggi untuk dapat mewujudkan cita-cita mereka sehingga mereka mampu mengerjakan tugas dengan lebih baik dan meyelesaikan tugas dengan hasil yang maksimal. Hasil maksimal yang diperoleh tentunya tidak terlepas dari dukungan dan motivasi dari orang-orang terdekat terutama dari orang tua mereka.

Kemampuan menulis menjadi hobi tersendiri bagi sebagian mahasiswa yang diwawancara yang berawal sejak masih Sekolah Menengah Pertama. Hal ini akan terus dilaksanakan dan dikembangkan karena kesadaran pentingnya menulis ini yang akan berdampak baik bagi proses kuliah terutama dalam penulisan dan penyusunan skripsi. Jika terdapat ganjalan dihati mereka akan menuangkan melalui tulisan, sehingga akan mengurangi beban fikiran yang ada. Selain itu terdapat mahasiswa yang pernah mengisi waktu luang dengan bekerja. Pekerjaan yang pernah dilakukan adalah sebagai kasir di Kamar Mandi Umum. Pekerjaan ini ditekuni selama kurang lebih 1 tahun sebelum dia mendaftarkan diri menjadi mahasiswa IAIN Metro.

Selama mengikuti proses perkuliahan mereka juga mengatakan bahwa mereka berperan aktif dalam perkuliahan dengan bertanya kepada dosen jika ada materi yang belum dipahami. Tidak hanya mengikuti kuliah dengan baik, mahasiswa juga bersaing secara wajar dalam meningkatkan kemampuan dan keaktifan. Ketika ada masalah apapun, mereka berusaha menyelesaikan permasalahannya secara individu, kemudian jika dirasa masalah yang dialami terlalu berat, maka mereka akan meminta tolong kepada teman yang lain.

Terkait dengan pemenuhan aksesibilitas penyandang disabilitas bahwa mereka dapat mengakses dan memperoleh layanan dengan baik dan tidak mengalami kendala yang berarti. Segala sesuatu yang berkaitan dengan akademik dapat mereka konsultasikan untuk kemudian memperoleh solusi agar perkuliahan dapat dilakukan dengan lancar. Senada dengan pelayanan, transportasi juga harus menjadi hal yang mudah untuk diakses. Salah seorang mahasiswa menyampaikan bahwa dia merasa kesulitan untuk sampai dikampus, sedangkan yang lain tidak 
menyebutkan karena mereka dapat sampai dikampus tanpa hambatan. Selain layanan dan transportasi, mahasiswa penyandang disabilitas juga harus mudah mengakses informasi. Informasi ini dapat diumumkan melalui website dan mading kampus. Komunikasi yang baik akan membangun hubungan yang baik pula. Secara umum keseluruhan objek penelitian tidak mengalami kendala dalam berkomunikasi. Setelah berinteraksi selama beberapa bulan, mereka dapat lebih diterima dan tidak ada tindakan diskriminatif.

Format Pendidikan inklusif di perguruan tinggi juga sangat penting untuk diperhatikan dengan mempertimbangkan standar fasilitas Pendidikan yang harus disiapkan oleh Lembaga Pendidikan bagi mahasiswa penyandang disabilitas. Berdasarkan hasil wawancara yang dilakukan diketahui bahwa mahasiswa memang telah mengikuti proses perkuliahan secara inklusif dan ramah terhadap lingkungan dengan artian mereka mengikuti proses perkuliahan dalam kelas yang sama dengan mereka yang tidak memiliki hambatan. Mahasiswa tetap dapat mengeksplor potensi yang ada pada diri dan mampu mengikuti pembelajaran secara aktif walau dengan keterbatasan.

Selain itu, interaksi antara mahasiswa penyandang diasbilitas dengan dosen sangat baik, sebagaimana digambarkan pada Tabel 2:

Tabel 2. Interaksi Mahasiswa dan Dosen

\begin{tabular}{|c|c|c|}
\hline \multicolumn{2}{|c|}{ INDIKATOR } & HASIL EVALUASI \\
\hline $\begin{array}{l}\text { Interaksi Sosial } \\
\text { Mahasiswa } \\
\text { Penyandang } \\
\text { Disabilitas } \\
\text { dengan dosen }\end{array}$ & Pembelajaran & $\begin{array}{l}\text { Dosen memberikan ruang apresiasi seluas- } \\
\text { luasnya kepada seluruh mahasiswa untuk } \\
\text { diskusi aktif, menuangkan pendapat dalam } \\
\text { setiap presentasi atau kegiatan } \\
\text { perkuliahan. } \\
\text { Mahasiswa berharap agar dosen tidak } \\
\text { mengucilkan atau terlalu } \\
\text { mengistimewakan kebradaan mahasiswa } \\
\text { penyandang disabilitas. Biarkan semua }\end{array}$ \\
\hline
\end{tabular}




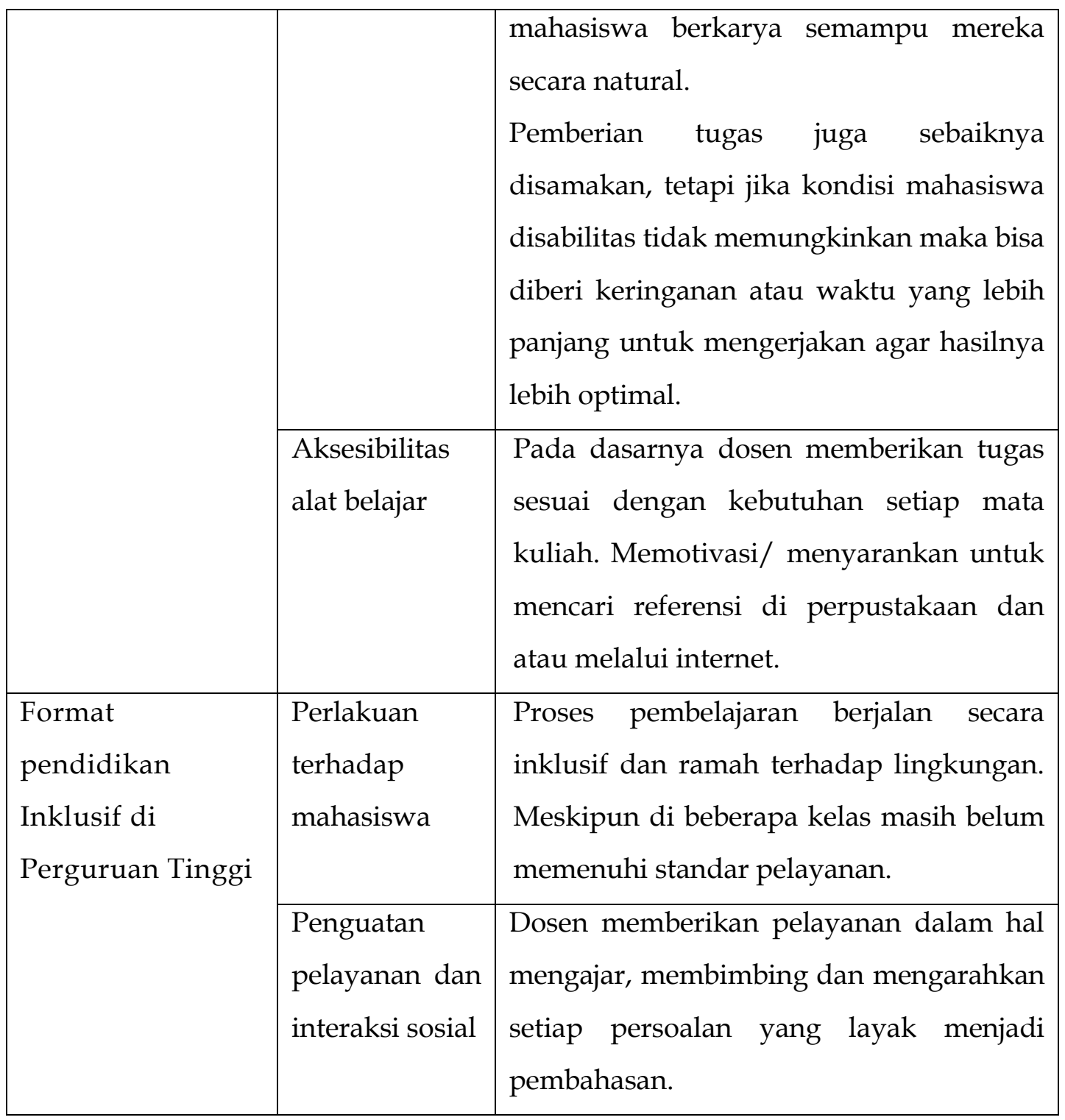

Berdasarkan hasil penelitian diatas dapat disimpulkan bahwa jika dalam satu kelas terdapat satu atau lebih mahasiswa disabilitas, maka kelas tersebut sudah termasuk kedalam kelas inklusif. Dosen harus memberikan ruang seluas-luasnya agar mahasiswa dapat mengeksplor segala kemampuan mereka, sehingga hasil belajar yang diperoleh pun akan maksimal. Mengenai aksesibilitas media belajar, dosen harus mendukung mahasiswa untuk tidak hanya belajar dikelas tetapi juga pergi ke perpus untuk mecari referensi penyelesaian tugas mahasiswa. Berikan penjelasan bahwa dengan pergi keperpustakaan dan membaca banyak buku maka akan semakin membuat cerdas pembaca itu sendiri. Mengerjakan tugas tidak hanya 
dapat diselesaikan dengan mencari buku di perpustakaan tetapi juga berasal dari sumber lain secara online.

Kondisi mahasiswa disabilitas yang berbeda sesuai dengan latar belakangnya tentu membutuhkan perlakuan yang berbeda pula sesuai dengan kondisi dan kebutuhan. Sebagai dosen hendaknya mampu lebih bijaksana dalam memberi perlakuan kepada mahasiswa dengan tidak merendahkan atau terlalu mengistimewakan mahasiswa penyandang disabilitas. Terkait dengan tugas yang harus dikerjakan oleh mahasiswa sebaiknya tidak dibedakan selama kondisi tersebut tidak menghambat mereka dalam menyelesaikan tugas. Kondisi kelas yang berada di lantai 2 dan 3 tentu menjadi pertimbangan sendiri karena dengan kondisi terbatas dan harus naik melalui anak tangga yang jumlahnya tidak sedikit dan ada beberapa gedung dengan kualitas tangga yang sempit dan curam. Hal ini tentu akan sangat membahayakan bagi para penyandang disabilitas terutama tuna netra dan tuna daksa. Dengan demikian diharapka pada pihak Lembaga untuk dapat mengevaluasi segala bangunan dan fasilitas lainnya yang ada dan kemudian akan disesuaikan.

Penjelasan diatas menunjukkan bahwa dosen mempunyai peran khusus terhadap pembentukan karakter mahasiswa baik normal maupun difabel. Hal ini karena dosen dapat selalu bertatap muka dengan seluruh mahasiswa dikelas setiap minggunya sehingga mampu melihat progress pembelajaran mahasiswa dari awal hingga akhir perkuliahan. Terkait dengan hal ini, kebijakan dari pihak Lembaga menjadi core keperdulian terhadap keberadaan mahasiswa disabilitas. Seperti dapat dilihat di Table 3:

Tabel 3. Interview dengan Unsur Pimpinan IAIN Metro

\begin{tabular}{|c|c|c|}
\hline \multicolumn{2}{|c|}{ INDIKATOR } & HASIL EVALUASI \\
\hline \multirow[t]{2}{*}{$\begin{array}{l}\text { Interaksi Sosial } \\
\text { Mahasiswa } \\
\text { Penyandang } \\
\text { Disabilitas }\end{array}$} & Pelayanan & $\begin{array}{l}\text { Lembaga memberikan ruang apresiasi } \\
\text { seluas-luasnya kepada seluruh } \\
\text { mahasiswa . baik perihal belajar } \\
\text { mengajar di kelas atau di Unit Kegiatan } \\
\text { Mahasiswa. }\end{array}$ \\
\hline & Aksesibilitas & $\begin{array}{l}\text { Kampus saat ini sedang didesain agar } \\
\text { memiliki akses yang mudah bagi seluruh }\end{array}$ \\
\hline
\end{tabular}




\begin{tabular}{|c|c|c|}
\hline & & $\begin{array}{l}\text { civitas akademika dengan segala } \\
\text { kelehiban dan keterbatasannya. }\end{array}$ \\
\hline \multirow[t]{2}{*}{$\begin{array}{l}\text { Format } \\
\text { pendidikan } \\
\text { Inklusif di } \\
\text { Perguruan } \\
\text { Tinggi }\end{array}$} & kebijakan & $\begin{array}{l}\text { Proses pembelajaran berjalan secara } \\
\text { inklusif dan ramah terhadap lingkungan } \\
\text { dengan akses yang memudahkan } \\
\text { khususnya pada Gedung-gedung yang } \\
\text { baru dibangun. }\end{array}$ \\
\hline & $\begin{array}{l}\text { Penguatan } \\
\text { pelayanan }\end{array}$ & $\begin{array}{l}\text { Kampus sedang mendesain aksesibilitas } \\
\text { publik agar dapat digunakan secara } \\
\text { inklusif. Artinya bahwa seluruh } \\
\text { pelayanan ke depan meliputi seluruh } \\
\text { aspek, tidak hanya penyandang } \\
\text { disabilitas tetapi semua pihak pengguna } \\
\text { fasilitas. }\end{array}$ \\
\hline
\end{tabular}

IAIN Metro memberikan perhatian khusus bagi para calon mahasiswa penyandang disabilitas, perhatian ini berupa pendampingan dari panitia dan ruang ujian diberikan secara terpisah dengan pendaftaran lain. Jika pendaftar normal melakukan tes ujian masuk di kelas, maka lain halnya penyandang disabilitas yang di tempatkan diruang khusus dan untuk pendaftar tuna netra, soal akan dibacakan oleh panitia dan calon mahasiswa mengisi jwaban yang dianggap benar. Pemberian perlakuan khusus ini dilakukan jika sebelum pelaksanaan ujian calon mahasiswa telah menginformasikan kondisi yang dialami kepada panitia.

Mengenai aksesibilitas, IAIN Metro juga tengah mempersiapkan fasilitas yang memadai yang dibutuhkan, tidak hanya bagi penyandang disabilitas, tetapi juga bagi ibu-ibu, anak-anak, dan orang lanjut usia. Hal ini diatur dalam Perencanaan dan Penganggaran Responsif Gender (PPRG). Hal ini bertujuan untuk mempermudah mahasiswa, wanita hamil, lanjut usia, atau yang memiliki keterbatasan lain. IAIN Metro merupakan salah satu kampus yang ditujuk langsung oleh Kementrian Agama sebagai anggota sosialisasi PPRG nasional.

Pembangunan gedung perkuliahan baru Fakultas Syariah yang berlokasi dikampus 2 menunjukkan bahwa IAIN Metro sangat memperdulikan keberadaan 
penyandang disabilitas. Hal ini terwujud dari bangunan kampus yang laintainya dapat diakses menggunakan kursi roda, dan dengan anak tangga yang landai. Bahkan beberapa tangga direnovasi agar lebih landau dan mudah diakses. Sementara ini memang belum semua Gedung perkuliahan yang berstandar PPRG, dan hal tersebut menjadi evaluasi sehingga rencana kedepan semua pembangunan Gedung akan dibangun sesuai standar yang mudah diakses. Dengan demikian tidak menutup kemungkinan untuk dapat mewujudkan kampus IAIN Metro dalam menerapkan program inklusi yang manfaatnya tidak hanya dirasakan oleh penyandang disabilitas tetapi juga semua pihak.

\section{Format Pendidikan Inklusif di Perguruan Tinggi}

Pendidikan inklusif adalah pendidikan yang memberikan kesamaan kesempatan kepada peserta didik penyandang disabilitas untuk belajar bersama dengan peserta didik lainnya, agar seluruh peserta didik dapat belajar atas dasar kesetaraan, sehingga mereka memiliki peluang yang sama untuk mencapai keberhasilan.

Penelitian tentang Pendidikan inklusif telah banyak dilakukan sejak tahun 1980-an. Sebagaimana penelitian yang dilakukan oleh The National Academy of Science (AS) menunjukkan bahwa klasifikasi dan penempatan anak berkelainan di sekolah, kelas atau tempat khusus adalah yang tidak effektif dan tergolong diskriminatif. Layanan ini merekomendasikan agar pendidikan khusus secara segregatif yang hanya diberikan secara terbatas berdasarkan hasil identifikasi yang tepat.

Beberapa pakar bahkan mengemukakan bahwa sangat sulit untuk melakukan identifikasi dan penempatan penyandang disabilitas secara tepat, karena karakteristik mereka yang sangat heterogen. Pendidikan inklusif dilandaskan atas asas kesamaan hak, non-diskriminatif, menerima perbedaan, saling menghargai, semangat kooperatif dan toleransi.

\section{E. Kesimpulan}

Berdasarkan hasil penelitian di atas dapat disimpulkan bahwa interaksi sosial sesama penyandang disabilitas serta mahasiswa regulerdi IAIN Metro, terjalin dengan 
baik. Termasuk interaksi sosial dengan para dosen dan seluruh karyawan di lingkungan IAIN Metro.

Meskipun IAIN Metro sudah berusaha memberikan pelayanan mental yang baik, namun belum dapat memberikan aksesibilitas yang luas terhadap penyandang disabilitas. Hal ini nampak pada segi arsitektural bangunan/infra struktur yang masih mengedepankan keberfungsian bagi civitas akademika yang tidak memiliki hambatan/disabilitas.

IAIN Metro secara profesional belum siap untuk menerapkan model pendidikan inklusif. Ketidaksiapan tersebut dapat dilihat dari beberapa hal yaitu: sarana dan prasarana yang tidak aksesibel dan kurang memadai bagi mahasiswa disabilitas, kurikulum yang digunakan belum disesuaikan dengan kondisi mahasiswa disabilitas, tidak adanya data base yang jelas, tidak ada tenaga pendamping bagi mahasiswa disabilitas, serta belum adanya pusat layanan mahasiswa disabilitas.

Berdasarkan hasil penelitian tersebut ada beberapa saran yang penulis rekomendasikan sebagai bahan pertimbangan dalam menyongsong berdirinya perguruan tinggi inklusif, yaitu:

IAIN Metro perlu mempersiapkan diri untuk mengimplementasikan pendidikan inklusif. Sebagai wujud manifestasi dari undang - undang nomor 8 tahun 2016 tentang Penyandang disabilitas, terutama mengenai hak-hak pendidikan yang sama. Oleh sebab itu, cepat atau lambat IAIN Metro harus bermetamorfose menjadi kampus inklusif. IAIN Metro perlu melakukan rekrutmen dosen yang memiliki kualifikasi pendidikan luar biasa. Hal ini dilakukan untuk memberikan pelayanan khusus pendidikan secara individual dalam keadaan yang mendesak.

Pemerintah sebagai policy maker (pembuat kebijakan) perlu mendukung implementasi pendidikan inklusif di perguruan tinggi agama Islam dengan cara membuat regulasi yang jelas. Disamping itu dukungan dana juga sangat diperlukan guna mengembangkan sistem pendidikan inklusif yang komprehensif.

\section{DAFTAR PUSTAKA}

Anas Sudijono. Pengantar Evaluasi Pendidikan. Jakarta: Raja Grafindo Persada, 2011.

Deddy Mulyana. Metodologi Penelitian Kualitatif, Paradigma Ilmu Komunikasi Dan Ilmu Sosial Lainnya. Jakarta: PT Remaja Rosda Karya, 2001. 
Eko Putro Widoyoko. Evaluasi Program Pembelajaran Panduan Praktis Bagi Pendidik Dan Calon Pendidik. Yogyakarta: Pustaka Pelajar, 2016.

Elly M. Setiadi. Ilmu Sosial Dan Budaya Dasar. Jakarta: Kencana Prenada Media Group, 2007.

Hadari Nawawi. Penelitian Terapan. Yogyakarta: Gajah Mada Universty Press, 1996.

Ngalim Purwanto. Prinsip-Prinsip Dan Teknik Evaluasi Pengajaran. Bandung: Remaja Rosdakarya, 2009.

Noeng Muhadjir. Metodologi Penelitian Kualitatif. Yogyakarta: Rake Sarasih, 1998.

Pemerintah Daerah Provinsi Lampung. Pelayanandan Pemenuhan Hak-Hak Penyandang Disabilitas, Pub. L. No. 10 (2013).

Ramayulis. Ilmu Pendidikan Islam. Jakarta: Kalam Mulia, 2011.

Ratminto, and Atik Septi Winarsih. Manajemen Pelayanan. Yogyakarta: Pustaka Pelajar, 2007.

Sanafiah Faisal. Format-Format Penelitian. Jakarta: PT Raja Grafindo Persada, 2001.

Sugiyono. Memahami Penelitian Kualitatif. Bandung: Alfabeta, 2015.

Suharsimi Arikunto. Prosedur Penelitian Suatu Pendekatan Praktik. Yogyakarta: Rineka Cipta, 2006.

Tjiptono Fandy. Prinsip-Prinsip Total Quality Service,Andi Offset. Yogyakarta: Andi Offset, 2005.

“Undang-Undang Republik Indonesia Nomor 2 Tahun 1989." Accessed January 10, 2019. https://jdih.kemenkeu.go.id/fulltext/1989/2TAHUN 1989UU.HTM.

“Undang-Undang Republik Indonesia Nomor 19 Tahun 2011." Accessed January 10, 2019. https://www.bphn.go.id/data/documents/11uu019.pdf.

“Undang-Undang Republik Indonesia Nomor 20 Tahun 2003." Accessed January 9, 2019.http:/ / kelembagaan.ristekdikti.go.id/wpcontent/uploads/2016/08/UU_no_20_th_2003.pdf.

Wina Sanjaya. Kurikulum Dan Pembelajaran:Teori Dan Praktik PengembanganKurikulum Tingkat Satuan Pendidikan (KTSP). Jakarta: Kencana, 2008.

Winarno Surakhmad. Pengantar Penelitian Ilmiah; Dasar, Metode Dan Teknik. Bandung: Tarsito, 1998. 
